\title{
Growth of Salmonella in napa cabbage kimchi during fermentation
}

\author{
Yukyung Choi ${ }^{1}$, Soomin Lee ${ }^{1}$, Heeyoung Lee $^{2}$, Hyun Jung $\mathrm{Kim}^{3}$, Sejeong Kim ${ }^{1}$, \\ Jimyeong $\mathrm{Ha}^{1}$, Jeeyeon Lee ${ }^{4}$, Hyemin $\mathrm{Oh}^{1}$, Yohan Yoon ${ }^{1,5 *}$ \\ ${ }^{1}$ Risk Analysis Research Center, Sookmyung Women's University, Seoul 04310, Korea \\ ${ }^{2}$ Food Standard Research Center, Korea Food Research Institute, Wanju 55365, Korea \\ ${ }^{3}$ Research Group of Consumer Safety, Korea Food Research Institute, Wanju 55365, Korea \\ ${ }^{4}$ Department of Food and Nutrition, Dong-eui University, Busan 47340, Korea \\ ${ }^{5}$ Department of Food and Nutrition, Sookmyung Women's University, Seoul 04310, Korea
}

\begin{abstract}
This study evaluated the growth of Salmonella in napa cabbage kimchi during fermentation. The Baranyi model was fitted to the Salmonella growth data to calculate lag phase duration (LPD), maximum specific growth rate $\left(\mu_{\max }\right)$, initiation time of decrease (ITD), shoulder period (SP), and death rate (DR). The effects of temperature on kinetic parameters were analyzed using a polynomial model. In the growth phase, LPD $(180.00-4.81 \mathrm{~h})$ decreased and $\mu_{\max }$ $(0.000-0.592 \log \mathrm{CFU} / \mathrm{g} / \mathrm{h})$ increased $(\mathbf{p}<0.05)$. However, ITD $(180-17 \mathrm{~h})$ decreased $(\mathbf{p}<\mathbf{0 . 0 5})$ as the temperature increased. In the death phase, SP $(14.95-1.04 \mathrm{~h})$ decreased and DR $\left(-0.018^{--0.306} \log\right.$ CFU/g/h) increased $(p<0.05)$ as the temperature increased. Secondary models on the kinetic parameters were proposed to describe the effect of temperature, with $R^{2}=\mathbf{0 . 6 0 6 - 0 . 9 5 6 , ~ a n d ~ t h e ~ p e r f o r m a n c e ~ [ r o o t ~ m e a n ~ s q u a r e ~ e r r o r ~ ( R M S E ) ~ v a l u e s : ~} 0.350$ (growth phase) and 0.428 (death phase)] was appropriate. The dynamic model demonstrated that Salmonella growth in napa cabbage kimchi increased during the initiation of fermentation and subsequently decreased at varying temperatures. Therefore, napa cabbage kimchi should be sufficiently fermented to decrease the risk of Salmonella infection.
\end{abstract}

Key words : dynamic model, fermentation, kimchi, predictive model, Salmonella

\section{Introduction}

Salmonella are gram-negative, facultative anaerobic, and mesophilic foodborne pathogen (Allerberger et al., 2003; FDA, 2012). Generally, Salmonella can grow and survive in animal-originated foods and fresh products (Cetin et al., 2020; Eng et al., 2015; Hyeon et al., 2011; Kim et al., 2018). In 2015, Salmonella was the second-most common cause (34\%) of foodborne outbreaks in the United States, after norovirus (37\%). Pork, seeded vegetables, and vegetable row crops were commonly responsible for these outbreaks (CDC, 2017).

Kimchi is a traditional side dish and the most widely consumed fermented food in South Korea, served by most restaurants and food services (Rhee et al., 2011). Kimchi has various health benefits conferred by the presence of lactic acid bacteria (LAB), organic acids, and bacteriocins (Park et al., 2014). LAB in kimchi are known to have antimicrobial effects against Salmonella, Staphylococcus aureus, Bacillus cereus, and Escherichia coli (Ahn et al., 2003). Although, kimchi is considered microbiologically safe, the safety and microbial risk of kimchi can vary, depending on several factors such as the fermentation period or the components of the raw materials used. Lee et al. (2017) showed that fresh kimchi has a low concentration of $\mathrm{LAB}$, which might be insufficient to suppress pathogens. In addition, kimchi

*Corresponding author. E-mail : yyoon@sm.ac.kr, Phone : +82-2-2077-7585, Fax : +82-2-710-9479

Received 14 August 2020; Revised 14 October 2020; Accepted 02 November 2020.

Copyright (c) The Korean Society of Food Preservation.

This is an Open Access article distributed under the terms of the Creative Commons Attribution Non-Commercial License (http://creativecommons.org/licenses/by-nc/4.0) which permits unrestricted non-commercial use, distribution, and reproduction in any medium, provided the original work is properly cited. 
can be cross-contaminated by Salmonella and other foodborne pathogens during manufacturing when the napa cabbage is soaked in the $\mathrm{NaCl}$ solution ( $\mathrm{Yu}$ et al., 2012). Thus, the causes of unexpected kimchi contamination outbreaks remain unclear (e.g., contamination of the raw ingredients of kimchi or contamination during manufacturing) (Cho et al., 2014; Patra et al., 2016).

To investigate the kinetic behavior of foodborne pathogens, predictive models have been used (Ha et al., 2016; Ha et al., 2019; Kim et al., 2017; Lee et al., 2014; Lee et al., 2019; Yoon et al., 2006). In these models, changes in bacterial cell counts depend on changes in time and kinetic parameters such as lag phase duration (LPD) and growth rate, which are calculated using a primary model. Secondary models are used to describe the effects of environmental factors, such as temperature, $\mathrm{pH}$, and water activity, on kinetic parameters (Lee et al., 2014; Lee et al., 2015).

The objective of this study was to develop predictive models to describe the kinetic behavior of Salmonella in napa cabbage kimchi during fermentation.

\section{Materials and methods}

\section{Napa cabbage kimchi preparation}

Raw ingredients, including napa cabbage (heading type), Korean white radish (Joseonmu), chives, ground garlic, ground ginger, and Korean red pepper powder were purchased from a grocery store in Seoul, South Korea. All ingredients were produced in Korea. The napa cabbage was salted with $10 \% \mathrm{NaCl}$ solution for $3 \mathrm{~h}$ and drained. The ingredients were first cut; 4-cm-long pieces of napa cabbage leaves, 5-cm-long pieces of white radish, and 5-cm-long pieces of chives were prepared. The ingredients $(1 \mathrm{~kg}$ of salted napa cabbage with $172 \mathrm{~g}$ sliced white radish, $16 \mathrm{~g}$ chives, $3.2 \mathrm{~g}$ ground ginger, $24 \mathrm{~g}$ ground garlic, $22 \mathrm{~g}$ powdered red pepper, and $2 \mathrm{~g}$ sugar) were then mixed thoroughly (KTKP, 2018; RDA, 2008). One-kilogram portions of napa cabbage kimchi were placed in a zip lock bag $(30 \times 45 \mathrm{~cm})$.

\section{Bacterial culture and inoculation}

Five Salmonella strains (S. enterica serovar Typhimurium NCCP10812, S. enterica serovar Agona NCCP12231, S. enterica serovar Enteritidis NCCP12243, S. enterica serovar
Montevideo NCCP10141, and S. enterica KACC11595) were used in this study. Single colonies of Salmonella were cultured in $10 \mathrm{~mL}$ tryptic soy broth (TSB) (Becton, Dickinson and Company, Franklin Lakes, NJ, USA) at $37^{\circ} \mathrm{C}$ for $24 \mathrm{~h}$. One hundred microliter aliquots of the cultures were transferred into $10 \mathrm{~mL}$ of fresh TSB and sub-cultured under the same conditions. The sub-cultured Salmonella strains were mixed, and $50 \mathrm{~mL}$ of the Salmonella mixture was centrifuged at $1,912 \times g$ and $4^{\circ} \mathrm{C}$ for $15 \mathrm{~min}$. The pellet was washed twice with phosphate-buffered saline (PBS) $(\mathrm{pH}$ 7.4; $0.2 \mathrm{~g}$ of $\mathrm{KH}_{2} \mathrm{PO}_{4}, 1.5 \mathrm{~g}$ of $\mathrm{Na}_{2} \mathrm{HPO}_{4} \cdot 7 \mathrm{H}_{2} \mathrm{O}, 8.0 \mathrm{~g}$ of $\mathrm{NaCl}$, and $0.2 \mathrm{~g}$ of $\mathrm{KCl}$ in $1 \mathrm{~L}$ of distilled water) and resuspended in PBS to obtain 6-7 log CFU/mL of inoculum. Twenty milliliters of the sub-cultures were inoculated onto kimchi from each zip lock bag to obtain 4-5 log CFU/g. Zip lock bags were massaged 30 times and placed into airtight plastic containers. The airtight plastic containers were stored at $4{ }^{\circ} \mathrm{C}, 10^{\circ} \mathrm{C}, 15^{\circ} \mathrm{C}, 25^{\circ} \mathrm{C}$, and $30^{\circ} \mathrm{C}$ for $48-384 \mathrm{~h}$ for fermentation.

\section{Microbiological analysis}

Fifty grams of kimchi samples from each ziplock bag $(n=4)$ were aseptically removed with a flame-sterilized tong, and placed in filter bags (3M, St. Paul, MN, USA) containing $100 \mathrm{~mL}$ of $0.1 \%$ buffered peptone water (BPW) and pummeled (BagMixer; Interscience, St. Nom, France) for $1 \mathrm{~min}$. The homogenates were serially diluted with $0.1 \%$ BPW, and the diluents were plated on xylose lysine deoxycholate (XLD) agar (Becton, Dickinson and Company) and Lactobacilli MRS agar (Becton, Dickinson and Company) for the isolation of Salmonella and lactic acid bacteria, respectively. All plates were incubated at $37^{\circ} \mathrm{C}$ for 24-48 h. The $\mathrm{pH}$ of the kimchi samples was measured using a $\mathrm{pH}$ meter (Thermo Fisher Scientific, Waltham, MA, USA).

\section{Calculation of kinetic parameters}

The Baranyi model (primary model) was fitted to Salmonella cell counts to calculate kinetic parameters using the DMfit program (Institute of Food Research, Norwich, UK) to fit the growth curve (Baranyi and Roberts, 1994). The kinetic parameters were described using primary models to calculate the LPD and maximum specific growth rate $(\mu$ $\max ; \log \mathrm{CFU} / \mathrm{g} / \mathrm{h}$ ) in the growth phase and death rate (DR; $\log \mathrm{CFU} / \mathrm{g} / \mathrm{h})$ in the death phase. The relationship between 
kinetic parameters and fermentation temperature was analyzed using a polynomial (secondary) model developed using SigmaPlot 10.0 (Systat Software, San Jose, CA, USA) based on the following equation:

\section{Kinetic parameter $=a+b \times$ Temp $+c \times$ Temp $^{2}$}

where Temp is the fermentation temperature, and $a, b$, and $c$ are constant values. To simulate the growth of Salmonella under varying temperatures, a dynamic model was developed in accordance with the developed primary and secondary models using the equation developed by Baranyi and Roberts (1994). The kimchi samples inoculated with Salmonella were stored at various temperatures $\left(4^{\circ} \mathrm{C}, 15^{\circ} \mathrm{C}\right.$, and $25^{\circ} \mathrm{C}$ ), and the temperature was changed twice every 24 $\mathrm{h}$. The actual temperatures were measured using a data logger (Testo 174H, Testo, Lenzkirch, Germany).

\section{Validation}

To evaluate the performance of the developed model, Salmonella-inoculated kimchi samples were stored at $20^{\circ} \mathrm{C}$ and $27^{\circ} \mathrm{C}$, and the cell counts of Salmonella were obtained as described above. These cell counts were used as the observed values which were then compared with the predicted values obtained through the simulation from the developed models at $20^{\circ} \mathrm{C}$ and $27^{\circ} \mathrm{C}$. The differences between the observed and predicted values were obtained by calculating the root mean square error (RMSE) using the following equation:

$$
\text { RMSE }=\sqrt{\sum(\text { observed } \text { value }- \text { predicted } \text { value })^{2} / \mathrm{n}}
$$

Similarly, to validate the simulation of Salmonella cell counts predicted by the dynamic model under varying temperatures, Salmonella-inoculated samples were stored at $4^{\circ} \mathrm{C}, 15^{\circ} \mathrm{C}$, and $25^{\circ} \mathrm{C}$, and the temperature settings were changed twice every $24 \mathrm{~h}$. The temperature changes were recorded using a data logger (Testo $174 \mathrm{H}$, Testo). The recorded temperatures were further used for the simulations in the dynamic model. During storage, Salmonella cell counts were enumerated as described above. The cell counts were then compared to the data predicted by the dynamic model simulation.

\section{Statistical analysis}

Kinetic parameters at each temperature were analyzed using the PROC GLM procedure of SAS $^{\circledR}$ v.9.3 (SAS Institute, Cary, NC, USA). Least square (LS) means for each kinetic parameter were compared using pairwise $t$-tests at $\alpha=0.05$.

\section{Results and discussion}

Proliferation of Salmonella in kimchi decreased as the population of LAB increased and as $\mathrm{pH}$ decreased, regardless of temperature (Fig. 1). However, Salmonella cell counts in kimchi were constant at $4-15^{\circ} \mathrm{C}$, but increased in the early phase of fermentation at $25^{\circ} \mathrm{C}$ and $30^{\circ} \mathrm{C}$, and subsequently decreased thereafter (Fig. 1D-E). Once napa cabbage kimchi is prepared, it is kept at room temperature for $12-24 \mathrm{~h}$ to accelerate fermentation. It is then either consumed or stored at $4^{\circ} \mathrm{C}$. According to the Salmonella cell count data, consumption or storage at $4^{\circ} \mathrm{C}$ after $12-24 \mathrm{~h}$ of fermentation at room temperature may increase the risk of Salmonella foodborne illness because Salmonella cell counts increased during the 12-24 $\mathrm{h}$ fermentation period, and remained constant during storage at $4^{\circ} \mathrm{C}$.

$\mathrm{LAB}$ counts increased from $4.7 \pm 0.6$ to $8.7 \pm 0.3 \mathrm{log}$ $\mathrm{CFU} / \mathrm{g}$, and $\mathrm{pH}$ decreased from $6.0 \pm 0.2$ to $4.2 \pm 0.1$ during fermentation. As the temperature increased, the LAB growth rate increased, and the $\mathrm{pH}$ decreased rapidly (Fig. 1), as described above. When increased to approximately $9 \log$ $\mathrm{CFU} / \mathrm{g}$ in kimchi, LAB showed strong antimicrobial activity against Salmonella by decreasing the $\mathrm{pH}$ and producing antimicrobials. Salmonella death might be caused by antimicrobial substances, lactic acid, or because of low $\mathrm{pH}$ generated by LAB during fermentation (De Keersmaecker et al., 2006; Park et al., 2005). During kimchi fermentation, the cell counts for Salmonella remained either constant or increased and subsequently decreased (Fig. 1). Thus, primary models were developed separately for the growth and death phases (Table 1 and Fig. 1). In the growth phase, LPD was $180.00,120.00,16.42,5.85$, and $4.81 \mathrm{~h}$ at $4^{\circ} \mathrm{C}$, $10^{\circ} \mathrm{C}, 15^{\circ} \mathrm{C}, 25^{\circ} \mathrm{C}$, and $30^{\circ} \mathrm{C}$, respectively (Table 1 ). However, $\mu_{\max }\left[0.000\left(4^{\circ} \mathrm{C}\right), 0.007\left(10^{\circ} \mathrm{C}\right), 0.033\left(15^{\circ} \mathrm{C}\right)\right.$, $0.302\left(25^{\circ} \mathrm{C}\right)$, and $\left.0.592\left(30^{\circ} \mathrm{C}\right) \log \mathrm{CFU} / \mathrm{g} / \mathrm{h}\right]$ showed increment with temperature $(\mathrm{p}<0.05) \quad$ (Table 1). The Salmonella cell counts then started to decrease after $180 \mathrm{~h}$ 
(A)

(B)
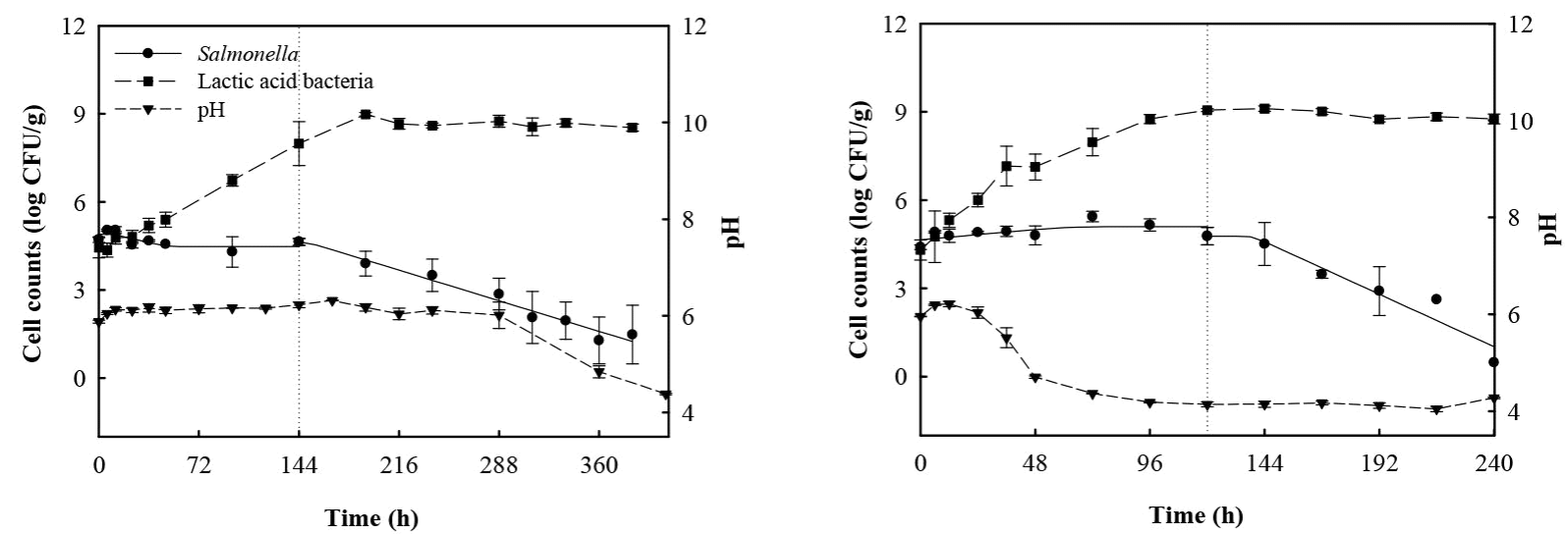

(C)

(D)
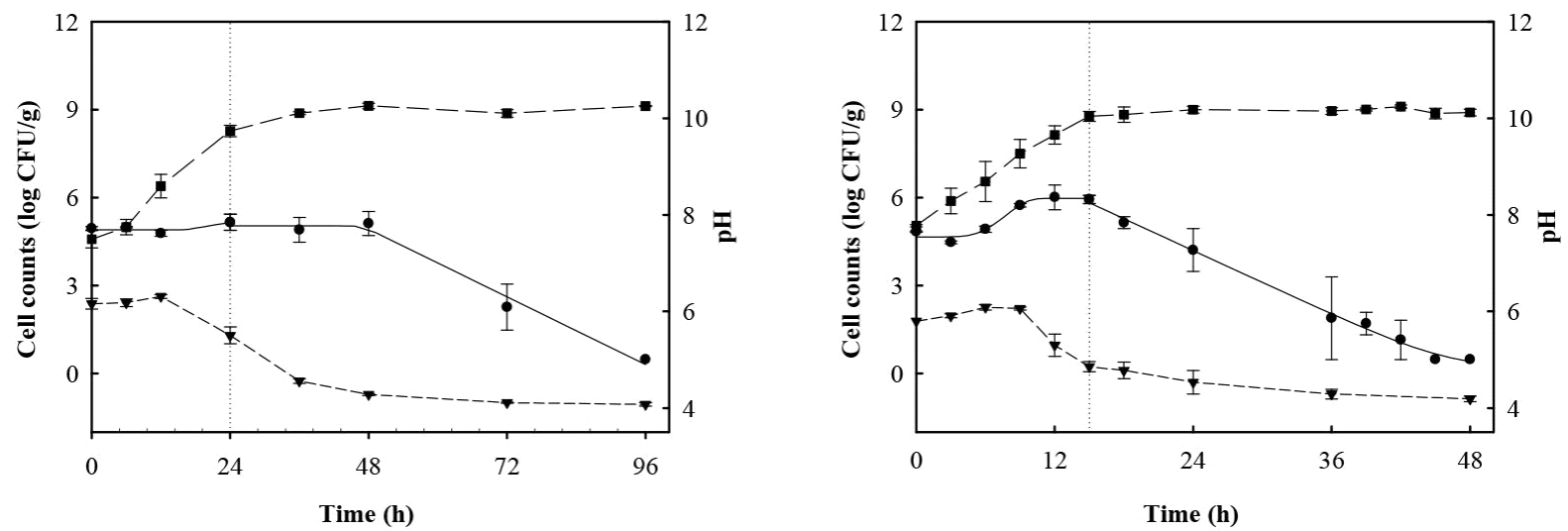

(E)

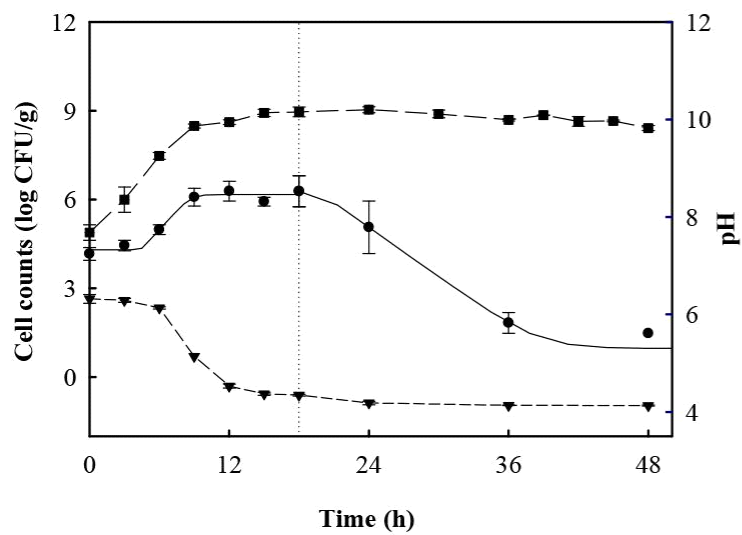

Fig. 1. Bacterial cell counts of Salmonella and lactic acid bacteria, and $\mathrm{pH}$ in napa cabbage kimchi during fermentation at $4^{\circ} \mathrm{C}(\mathrm{A}), 1^{\circ} \mathrm{C}$ (B), $15^{\circ} \mathrm{C}(\mathrm{C}), 25^{\circ} \mathrm{C}$ (D), and $30^{\circ} \mathrm{C}$ (E). 
Table 1. Kinetic parameters (LPD, $\mathrm{N}_{0}, \mu_{\max }$, ITD, SP, and DR) calculated by the Baranyi model for the growth of Salmonella in napa cabbage kimchi

\begin{tabular}{|c|c|c|c|c|c|c|c|c|}
\hline \multirow{2}{*}{$\begin{array}{l}\text { Temperature } \\
\text { (C) }\end{array}$} & \multicolumn{4}{|c|}{ Growth phase } & \multirow{2}{*}{$\begin{array}{c}\left.\mathrm{ITD}^{4}\right) \\
\text { (h) }\end{array}$} & \multicolumn{3}{|c|}{ Death phase } \\
\hline & $\begin{array}{l}\operatorname{LPD}^{1)} \\
\text { (h) }\end{array}$ & $\begin{array}{c}\mathrm{N}_{0}^{2)} \\
\left(\log \mathrm{CFU} \cdot \mathrm{g}^{-1}\right)\end{array}$ & $\begin{array}{c}\mu_{\max }^{3)} \\
\left(\log \mathrm{CFU} \cdot \mathrm{g}^{-1} \cdot \mathrm{h}^{-1}\right)\end{array}$ & $\mathrm{R}^{2}$ & & $\begin{array}{l}\mathrm{SP}^{5)} \\
\text { (h) }\end{array}$ & $\begin{array}{c}\left.\mathrm{DR}^{6}\right) \\
\left(\log \mathrm{CFU} \cdot \mathrm{g}^{-1} \cdot \mathrm{h}^{-1}\right)\end{array}$ & $\mathrm{R}^{2}$ \\
\hline 4 & $180.00 \pm 51.00^{\mathrm{a}^{*}}$ & $5.0 \pm 0.2^{\mathrm{a}}$ & $0.000 \pm 0.000^{\mathrm{b}}$ & 0.484 & $180 \pm 5^{\mathrm{a}}$ & $14.95 \pm 13.26^{\mathrm{a}}$ & $-0.018 \pm 0.004^{\mathrm{c}}$ & 0.809 \\
\hline 10 & $120.00 \pm 0.00^{\mathrm{ab} *}$ & $4.7 \pm 0.0^{\mathrm{a}}$ & $0.007 \pm 0.000^{\mathrm{b}}$ & 0.103 & $120 \pm 0^{\mathrm{ab}}$ & $19.02 \pm 0.00^{\mathrm{a}}$ & $-0.037 \pm 0.000^{\mathrm{bc}}$ & 0.801 \\
\hline 15 & $16.42 \pm 0.00^{\mathrm{bc}}$ & $4.9 \pm 0.0^{\mathrm{a}}$ & $0.033 \pm 0.000^{\mathrm{b}}$ & 0.003 & $24 \pm 0^{\mathrm{b}}$ & $22.84 \pm 0.00^{\mathrm{a}}$ & $-0.096 \pm 0.000^{\mathrm{bc}}$ & 0.914 \\
\hline 25 & $5.85 \pm 0.60^{\mathrm{bc}}$ & $4.6 \pm 0.1^{\mathrm{a}}$ & $0.302 \pm 0.012^{\mathrm{ab}}$ & 0.907 & $17 \pm 2^{\mathrm{b}}$ & $0.00 \pm 0.00^{\mathrm{a}}$ & $-0.149 \pm 0.045^{\mathrm{b}}$ & 0.930 \\
\hline 30 & $4.81 \pm 0.56^{\mathrm{c}}$ & $4.5 \pm 0.3^{\mathrm{a}}$ & $0.592 \pm 0.233^{\mathrm{a}}$ & 0.760 & $17 \pm 2^{\mathrm{b}}$ & $1.04 \pm 0.80^{\mathrm{a}}$ & $-0.306 \pm 0.039^{\mathrm{a}}$ & 0.922 \\
\hline
\end{tabular}

${ }^{1)} \mathrm{LPD}$, lag phase duration.

${ }^{2)} \mathrm{N}_{0}$, initial bacterial cell counts

${ }^{3)} \mu_{\max }$, maximum specific growth rate.

${ }^{4)}$ ITD, initiation time of decrease, time of decrease in bacterial cell counts.

${ }^{5)} \mathrm{SP}$, shoulder period.

${ }^{6} \mathrm{DR}$, death rate.

* Observed value.

${ }^{\mathrm{a}-\mathrm{c}}$, different letters mean significantly different at $\mathrm{p}<0.05$.

at $4^{\circ} \mathrm{C}, 120 \mathrm{~h}$ at $10^{\circ} \mathrm{C}, 24 \mathrm{~h}$ at $15^{\circ} \mathrm{C}$, and $17 \mathrm{~h}$ at $25^{\circ} \mathrm{C}$ and $30^{\circ} \mathrm{C}$ after fermentation (Table 1). In the death phase, SP decreased $\left[14.95\left(4^{\circ} \mathrm{C}\right), 19.02\left(10^{\circ} \mathrm{C}\right), 22.84\left(15^{\circ} \mathrm{C}\right), 0.00\left(25^{\circ} \mathrm{C}\right)\right.$, and $\left.1.04 \mathrm{~h}\left(30^{\circ} \mathrm{C}\right)\right]$, and DR increased [-0.018 $\left(4^{\circ} \mathrm{C}\right),-0.037$ $\left(10^{\circ} \mathrm{C}\right),-0.096\left(15^{\circ} \mathrm{C}\right),-0.149\left(25^{\circ} \mathrm{C}\right)$, and $-0.306\left(30^{\circ} \mathrm{C}\right) \log$ $\mathrm{CFU} / \mathrm{g} / \mathrm{h}](\mathrm{p}<0.05)$ as the temperature increased. The lower fermentation temperatures showed longer LPD, lower $\mu_{\max }$, and lower DR. Secondary models were developed for the kinetic parameters (LPD, $\mu_{\max }$, ITD, SP, and DR) with a

\section{(A)}

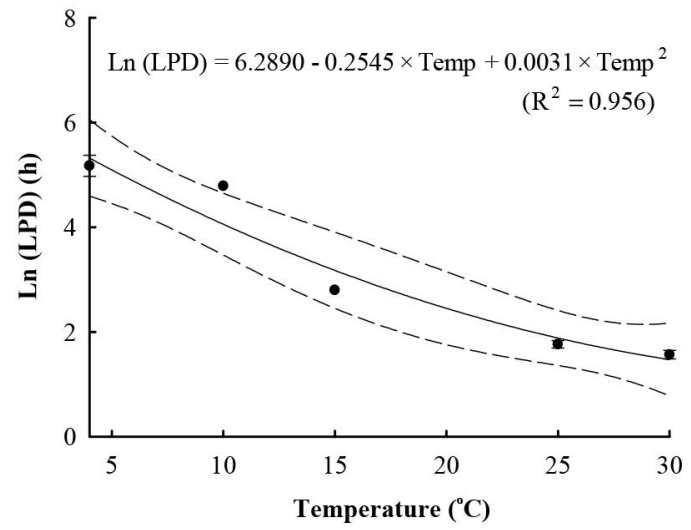

polynomial model $\left(\mathrm{R}^{2}=0.606-0.956\right)$ (Fig. 2). Validation of the performance of the developed predictive models was confirmed through an additional experiment conducted at $20^{\circ} \mathrm{C}$ and $27^{\circ} \mathrm{C}$, where the RMSE values were 0.350 (growth phase) and 0.428 (death phase). This result indicates that the developed models were appropriate for predicting the kinetic behavior of Salmonella in kimchi. In addition, a dynamic model was developed to demonstrate the changes in Salmonella cell counts in kimchi at varying temperatures
(B)

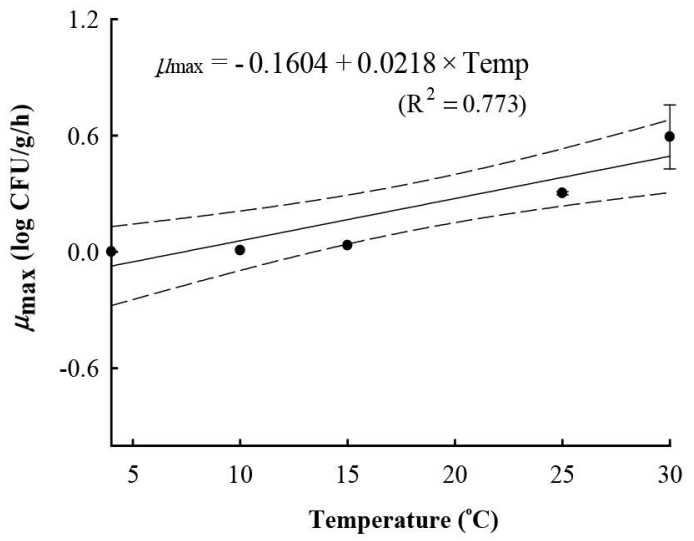

Fig. 2. Secondary model (polynomial model) for the effect of temperature on the kinetic parameters for the growth of Salmonella in napa cabbage kimchi during fermentation.

A, lag phase duration (LPD); B, maximum specific growth rate ( $\left.\mu_{\max }\right)$; $\mathrm{C}$, shoulder period (SP); D, death rate (DR); E, initiation time of decrease (ITD). 
(C)

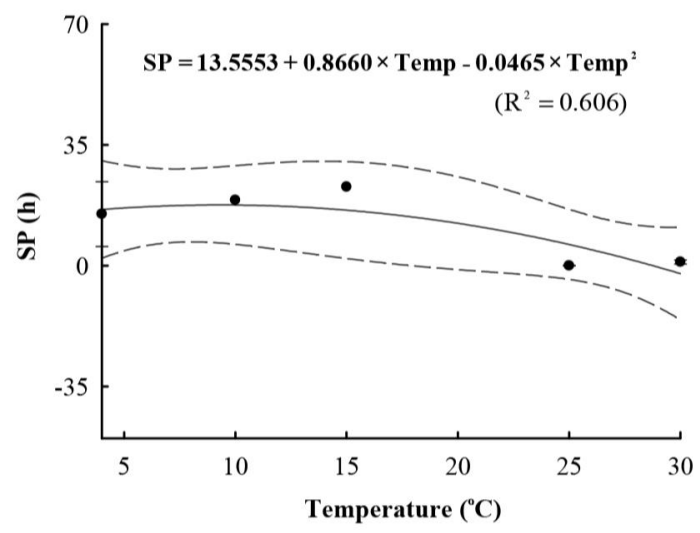

(E)

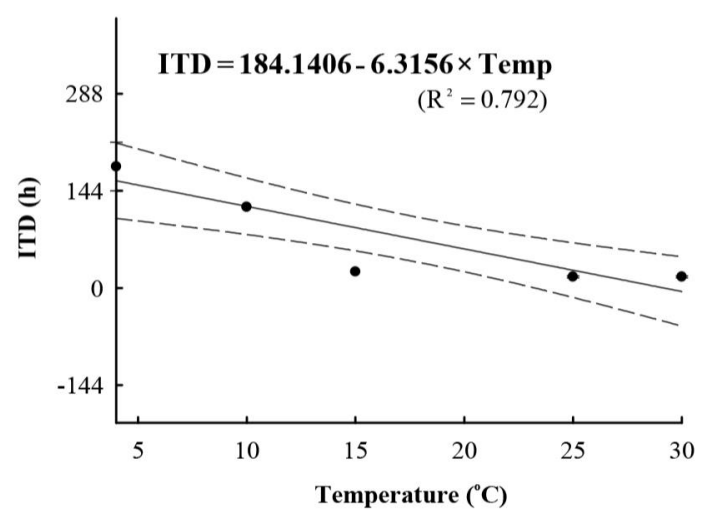

(4-25 $\mathrm{C})$. In simulations with the dynamic model, Salmonella cell counts increased from $4.7 \mathrm{log} \mathrm{CFU} / \mathrm{g}$ to 6.9 $\log \mathrm{CFU} / \mathrm{g}$ after $46 \mathrm{~h}$, and then decreased to $0.8 \log \mathrm{CFU} / \mathrm{g}$ after $135 \mathrm{~h}$ of fermentation. This dynamic model also showed that Salmonella can grow after the initiation of fermentation, as shown in the primary models (Fig. 3).

In conclusion, if Salmonella contaminates napa cabbage kimchi during manufacture, the pathogen can multiply for 17-24 $\mathrm{h}$ during fermentation, but perishes at $15-30^{\circ} \mathrm{C}$ due to an increase in LAB. However, Salmonella can resist or grow slowly at $4^{\circ} \mathrm{C}$ and $10^{\circ} \mathrm{C}$. Therefore, napa cabbage kimchi should be consumed at least after $384 \mathrm{~h}$ of fermentation at $4^{\circ} \mathrm{C}$, and at least after $48 \mathrm{~h}$ of fermentation at $25-30^{\circ} \mathrm{C}$. In addition, the developed models can be applied to describe
(D)

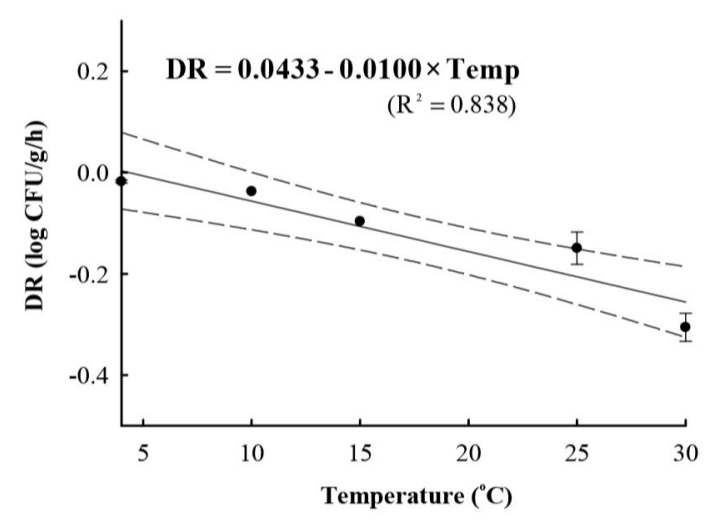

(continued)

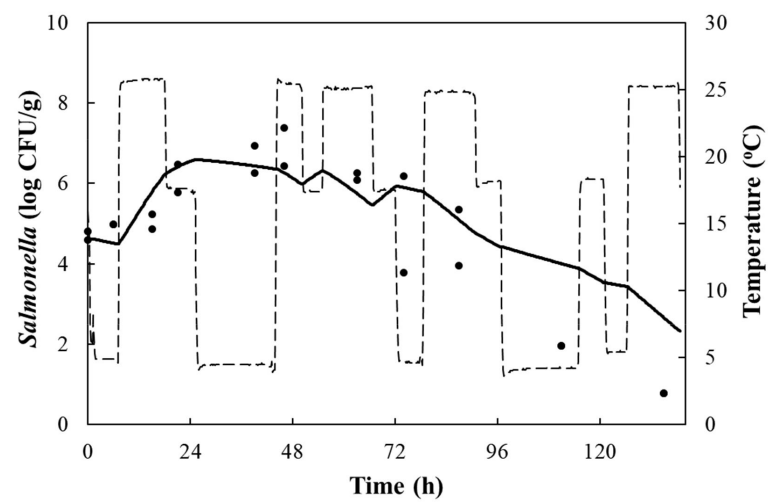

Fig. 3. Dynamic growth model of Salmonella in napa cabbage kimchi at varying temperature $\left(4-25^{\circ} \mathrm{C}\right)$ during fermentation: symbol, observed value; line, predicted line; and dotted line, fermentation temperature. 
or predict the kinetic behavior of Salmonella in napa cabbage kimchi during fermentation.

\section{Acknowledgements}

This research was supported by Main Research Program E0142101-02 of the Korea Food Research Institute (KFRI) funded by the Ministry of Science and ICT.

\section{Conflict of interests}

The authors declare no potential conflict of interest.

\section{ORCID}

Yukyung Choi https://orcid.org/0000-0002-7994-9862

Yohan Yoon

\section{References}

Ahn DK, Han TW, Shin HY, Jin IN, Ghim SY. Diversity and antibacterial activity of lactic acid bacteria isolated from kimchi. Kor J Microbiol Biotechnol, 31, 191- 196 (2003)

Allerberger F, Liesegang A, Grif K, Khaschabi D, Prager R, Danzl J, Hock F, Ottl J, Dierich MP, Berghold C, Neckstaller I, Tschape H, Fisher I. Occurrence of Salmonella enterica serovar Dublin in Austria. Wien Med Wochenschr, 153, 148-152 (2003)

Baranyi J, Roberts TA. A dynamic approach to predicting bacterial growth in food. Int $\mathrm{J}$ Food Microbiol, 23, 277-294 (1994)

CDC (Centers for Disease Control and Prevention). Surveillance for Foodborne Disease Outbreaks, United States, 2015, Annual Report, Atlanta, Georgia, USA, p2-8 (2017)

Cetin E, Temelli S, Eyigor A. Nontyphoid Salmonella prevalence, serovar distribution and antimicrobial resistance in slaughter sheep. Food Sci Anim Resour, 40, 21-33 (2020)

Cho SH, Kim J, Oh KH, Hu JK, Seo J, Oh SS, Hur MJ, Choi YH, Youn SK, Chung GT, Choe YJ. Outbreak of enterotoxigenic Escherichia coli O169 enteritis in school children associated with consumption of kimchi, Republic

of Korea. Epidemiol Infect, 142, 616-623 (2014)

De Keersmaecker SCJ, Verhoeven TLA, Desair J, Marchal K, Vanderleyden J, Nagy I. Strong antimicrobial activity of Lactobacillus rhamnosus GG against Salmonella typhimurium is due to accumulation of lactic acid. FEMS Microbiol Lett, 259, 89-96 (2006)

Eng SK, Pusparajah P, Ab Mutalib NS, Ser HL, Chan KG, Lee LH. Salmonella: A review on pathogenesis, epidemiology and antibiotic resistance. Front Life Sci, 8, 284-293 (2015)

FDA (Food and Drug Administration). Bad Bug Book ( $2^{\text {nd }}$ ed.). Handbook of Foodborne Pathogenic Microorganisms and Natural Toxins, Salmonella species, Silver Spring, MD, USA, p9 (2012)

Ha J, Gwak E, Oh MH, Park B, Lee J, Kim S, Lee H, Lee S, Yoon Y, Choi KH. Kinetic behavior of Salmonella on low $\mathrm{NaNO}_{2}$ sausages during aerobic and vacuum storage. Food Sci Anim Resour, 36, 262-266 (2016)

Ha J, Lee J, Lee S, Kim S, Choi Y, Oh H, Kim Y, Lee Y, Seo Y, Yoon Y. Mathematical models to describe the kinetic behavior of Staphylococcus aureus in jerky. Food Sci Anim Resour, 39, 371-378 (2019)

Hyeon JY, Chon JW, Hwang IG, Kwak HS, Kim MS, Kim SK, Choi IS, Song CS, Park C, Seo KH. Prevalence, antibiotic resistance, and molecular characterization of Salmonella serovars in retail meat products. J Food Prot, 74, 161-166 (2011)

Kim S, Jeong J, Lee H, Lee J, Lee S, Ha J, Choi Y, Yoon Y, Choi KH. Kinetic behavior of Campylobacter jejuni in beef tartare at cold temperatures and transcriptomes related to its survival. J Food Prot, 80, 2127-2131 (2017)

Kim YJ, Moon HJ, Lee SK, Song BR, Lim JS, Heo EJ, Park HJ, Wee SH, Moon JS. Development and validation of predictive model for Salmonella growth in unpasteurized liquid eggs. Food Sci Anim Resour, 38, 442-450 (2018)

KTKP (Korean traditional knowledge portal). http://www.ko reantk.com/ktkp2014/food/food-view.view?foodCd=TF1 0003292\&tempLang=en (accessed July 2018)

Lee H, Kim K, Lee S, Han M, Yoon Y. Growth kinetics of Staphylococcus aureus on brie and camembert cheeses. J Dairy Res, 81, 252-256 (2014)

Lee H, Kim K, Lee S, Yoon Y. Kinetic behaviour of Staphylococcus aureus on cheese as a function of water 
activity and temperature. J Dairy Res, 82, $64-69$ (2015) Lee HW, Yoon SR, Kim SJ, Lee HM, Lee JY, Lee JH, Kim $\mathrm{SH}$, Ha JH. Identification of microbial communities, with a focus on foodborne pathogens, during kimchi manufacturing process using culture-independent and -dependent analyses. LWT-Food Sci Technol, 81, 153159 (2017)

Lee J, Lee H, Lee S, Kim S, Ha J, Choi Y, Oh H, Kim Y, Lee Y, Yoon KS, Seo K, Yoon Y. Quantitative microbial risk assessment for Campylobacter jejuni in ground meat products in Korea. Food Sci Anim Resour, 39, 565-575 (2019)

Lee S, Yoon Y, Kim DM, Kim DS, Park KH, Chun HS. Mathematical models to predict kinetic behavior and aflatoxin production of Aspergillus flavus under various temperature and water activity conditions. Food Sci Biotechnol, 23, 975-982 (2014)

Park JH, Seok SH, Cho SA, Baek MW, Lee HY, Kim DJ, Chung MJ, Kim SD, Hong UP, Park JH. Antimicrobial effect of lactic acid producing bacteria culture condensate mixture (LCCM) against Salmonella Enteritidis.
Int J Food Microbiol, 101, 111-117 (2005)

Park KY, Jeong JK, Lee YE, Daily III JW. Health benefits of kimchi (Korean fermented vegetables) as a probiotic food. J Med Food, 17, 6-20 (2014)

Patra JK, Das G, Paramithiotis S, Shin HS. Kimchi and other widely consumed traditional fermented foods of Korea: A review. Front Microbiol, 7, Article 1493 (2016)

RDA (Rural Development Administration). Korea Traditional Local Food: 1-Usual Dishes. Paju, Gyeonggi Province, Kyomunsa Press. (2008)

Rhee SJ, Lee JE, Lee CH. Importance of lactic acid bacteria in Asian fermented foods. Microb Cell Fact, 10, S5 (2011)

Yoon Y, Skandamis PN, Kendall PA, Smith GC, Sofos JN. A predictive model for the effect of temperature and predrying treatments in reducing Listeria monocytogenes populations during drying of beef jerky. J Food Prot, 69, 62-70 (2006)

$\mathrm{Yu}$ DJ, Shin YJ, Choi DW, Song KB. Inactivation of Salmonella in salted water used for kimchi production. Food Control, 26, 322-325 (2012) 